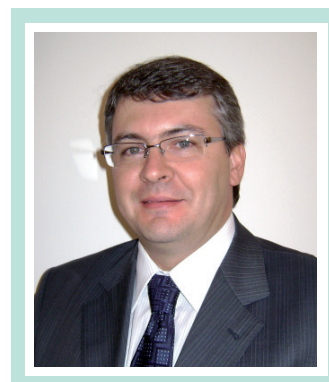

\section{Grande missão}

Foi com grande satisfação que recebi o convite do Dr. Antonio Carlos Chagas para ser o Editor Chefe dos Arquivos Brasileiros de Cardiologia para o biênio 20082009. Uma tarefa árdua, porém muito gratificante, uma vez que assumo o comando de uma revista de grande importância no cenário cardiológico, com estrutura profissional, e que é um grande patrimônio da nossa Sociedade Brasileira de Cardiologia, fruto do trabalho dos Editores que me antecederam, que construíram passo a passo a trajetória vitoriosa que presenciamos hoje.

Desde fevereiro de 2006 venho trabalhando no processo editorial da revista, colaborando com o Dr. Fábio Vilas-Boas, período no qual pude presenciar importantes mudanças, que tornaram a nossa revista mais dinâmica, culminando com o objetivo buscado intensamente, que foi a indexação na base ISI/Thomson Scientific.

Já a partir de 2008, poderemos ser avaliados para aumentar o fator de impacto da revista e também, naturalmente, receber classificação da Coordenação de Aperfeiçoamento de Pessoal de Nível Superior (Capes) como revista Qualis B Internacional. Esse fato automaticamente coloca os Arquivos Brasileiros de Cardiologia como uma das principais revistas da América Latina, podendo ser, em curto espaço de tempo, o grande fórum para publicações das pesquisas cardiológicas do continente. Essa conquista não é importante somente para os pesquisadores, mas também para todos os cardiologistas que se acostumaram a ler a revista, uma vez que receberão material cada vez mais aprimorado, equiparando-se aos principais periódicos internacionais.
As metas que pretendemos implementar para os próximos dois anos, em conjunto com os Editores Associados que assumirão comigo esta grande missão, são: política de valorização de contribuições originais oriundas das Pós-Graduações, conseqüentemente gerando citações da revista e elevando o seu fator de impacto; proporcionar aos revisores um modelo mais prático, de fácil acesso pelo sistema on-line; agilização do processo de submissão até a publicação do artigo, a fim de atrair cada vez mais pesquisadores nacionais e internacionais a publicar na revista; aprimorar a página eletrônica, tornando-a mais ágil e informativa aos autores e revisores e aumentar o número de artigos a serem submetidos no biênio 2008-2009, priorizando artigos originais nacionais e internacionais, encurtando o tempo entre submissão e publicação, que hoje é de aproximadamente 6 meses.

Para atingir tais objetivos é de fundamental importância que a nossa comunidade cardiológica continue prestigiando a nossa revista, enviando contribuições originais que uma vez publicadas, serão avaliadas nas respectivas áreas para receber, ao final do ano, o Prêmio ABC de Publicação Científica, o qual vem se consolidando como importante evento de reconhecimento aos melhores trabalhos publicados durante o ano. Em 2008, juntamente com a premiação dos trabalhos, estaremos comemorando os 60 anos de fundação da revista, verdadeiramente um grande feito.

Estarei à disposição para receber sugestões e críticas que poderão ser encaminhadas ao meu endereço pessoal. Convido a todos a participar da revista.

Cordialmente,
Fernando Bacal
Editor-Chefe 